\title{
MAML1 wt Allele
}

National Cancer Institute

\section{Source}

National Cancer Institute. MAML1 wt Allele. NCI Thesaurus. Code C114486.

Human MAML1 wild-type allele is located in the vicinity of $5 q 35$ and is approximately 64 $\mathrm{kb}$ in length. This allele, which encodes mastermind-like protein 1, plays a role in the modulation of notch signaling-dependent transcription. 